\title{
Inhibiting DNA-PKcs in a non-homologous end-joining pathway in response to DNA double-strand breaks
}

\author{
Jun Dong ${ }^{1, *}$, Tian Zhang ${ }^{1, *}$, Yufeng Ren ${ }^{1, *}$, Zhenyu Wang ${ }^{1, *}$, Clifton C. Ling ${ }^{2}$, Fuqiu \\ $\mathrm{He}^{2}$, Gloria C. $\mathrm{Li}^{2}$, Chengtao Wang ${ }^{1}$, Bixiu Wen ${ }^{1,2}$ \\ ${ }^{1}$ Department of Radiation Oncology, The First Affiliated Hospital, Sun Yat-sen University, Guangzhou 510080, China \\ ${ }^{2}$ Department of Medical Physics and Radiation Oncology, Memorial Sloan-Kettering Cancer Center, New York, NY 10021, USA \\ *Co-first author
}

Correspondence to: Bixiu Wen, email: wenbix@mail.sysu.edu.cn Chengtao Wang, email: wangcht5@mail.sysu.edu.cn

Keywords: DNA-PKCS, non-homologous end-joining, double-strand break, NU7441, nasopharyngeal carcinoma

Received: September 08, 2016

Accepted: January 25, 2017

Published: February 07, 2017

\section{ABSTRACT}

DNA-dependent protein kinase catalytic subunit (DNA-PKCs) is a distinct factor in the non-homologous end-joining (NHEJ) pathway involved in DNA double-strand break (DSB) repair. We examined the crosstalk between key proteins in the DSB NHEJ repair pathway and cell cycle regulation and found that mouse embryonic fibroblast (MEF) cells deficient in DNA-PKcs or Ku70 were more vulnerable to ionizing radiation (IR) compared with wildtype cells and that DSB repair was delayed. $\gamma \mathrm{H} 2 \mathrm{AX}$ was associated with phospho-Ataxiatelangiectasia mutated kinase (Ser1987) and phospho-checkpoint effector kinase 1 (Ser345) foci for the arrest of cell cycle through the G2/M phase. Inhibition of DNA-PKcs prolonged IR-induced G2/M phase arrest because of sequential activation of cell cycle checkpoints. DSBs were introduced, and cell cycle checkpoints were recruited after exposure to IR in nasopharyngeal carcinoma SUNE-1 cells. NU7441 radiosensitized MEF cells and SUNE-1 cells by interfering with DSB repair. Together, these results reveal a mechanism in which coupling of DSB repair with the cell cycle radiosensitizes NHEJ repair-deficient cells, justifying further development of DNA-PK inhibitors in cancer therapy.

\section{INTRODUCTION}

Cell cycle checkpoints are governed primarily by the kinase Ataxia-telangiectasia mutated (ATM) and Ataxiatelangiectasia and Rad3-related (ATR). DSB results in activation of ATM, which triggers phosphorylation of checkpoint effector kinase (CHK2), leading to the arrest of G1/S checkpoints, whereas the intra-S phase or G2/M checkpoints are blocked by CHK1 and activated by ATR. There is strong crosstalk between the ATM-CHK2 and ATR-CHK1 pathways, which relays and thus amplifies the cellular damage signal by phosphorylating many DNA damage response (DDR) proteins [4, 8-11].

DNA-dependent protein kinase catalytic subunit (DNA-PKcs), a member of the phosphatidylinositol 3-kinase (PI3K) family, represents a central component in NHEJ repair. DNA-PKcs is recruited to the DSB site and binds to the $\mathrm{Ku} 70 / 80$ heterodimer to form the DNA repair complex, which activates the kinase activity of DNA-PKcs through phosphorylation of the serine/threonine [12]. Our previous studies have validated that the absence of $\mathrm{Ku}$ protein compromises the ability of cells to repair DSB via the NHEJ repair pathway, elevates radiosensitivity, and enhances radiation-induced apoptosis $[13,14]$.

Studies have suggested a connection between reduced levels of ATM and alleviated levels of DNA-PKcs, which may rely on downstream substrates after exposure to $\operatorname{IR}[15,16]$. G2/M phase arrest arises and persists even at 24 to $48 \mathrm{~h}$ post-irradiation by inhibition of DNA-PKcs in ATM-deficient cells [15]. These data indicate the involvement of DNA-PKcs in DSB repair and its regulatory role in cell cycle progression.

There are comprehensive links among DNA repair, cell cycle progression and genome integrity in different cell lines. In radioresistant prostate cancer cells, the combination of PI3K $/ \mathrm{mTOR}$ inhibitor with irradiation suppresses colony formation, enforces $\mathrm{G} 2 / \mathrm{M}$ phase arrest and maintains high levels of DSB [17]. Cisplatin radiosensitizes non-small cell lung cancer cells via phosphorylation of ATM and autophagy [18]. However, the mechanism of DSB repair involved in NHEJ mediated by cell checkpoint(s) still remains unclear. 
Here, using NHEJ-deficient cells in which DNAPKcs and Ku70 genes were knocked down, we sought to gain mechanistic insights into the crosstalk between key proteins involved in the DSB NHEJ repair pathway and cell cycle regulation. We used a DNA-PK inhibitor to explore the synergistic effect on inhibition of DSB repair following IR exposure in NHEJ-competent or -deficient cells and a cancer cell line from a nasopharyngeal carcinoma (NPC) patient.

\section{RESULTS}

\section{Deficiency of DNA-PKes increases sensitivity to irradiation}

To investigate the role of DNA-PKcs in response to IR, we used mouse embryonic fibroblast (MEF), DNA$\mathrm{PKcs}^{-1-} \mathrm{MEF}$, and $\mathrm{Ku} 70^{-/-} \mathrm{MEF}$ cell lines to evaluate their differences in radiosensitivity. Western blot analysis was conducted to reveal the loss of $\mathrm{Ku} 70$ protein in $\mathrm{Ku} 70^{-/-}$ cells and DNA-PKcs protein expression in DNA-PKcs ${ }^{-1}$ cells (Figure 1A). All cell lines were exposed to irradiation at graded doses $(0,2,4,6$, and $8 \mathrm{~Gy})$, and survival was determined using the colony formation assay. The results indicated that irradiation induced a reduction of cell survival probability in DNA-PKcs ${ }^{-/}$and $\mathrm{Ku}^{-/-}$cells compared with their wild-type MEF cells (Figure 1B).

NU7441, a specific DNA-PK inhibitor, was used to investigate any synergistic effect when combined with irradiation in MEF, DNA-PKcs ${ }^{-/}$MEF and $\mathrm{Ku}^{-10^{--}} \mathrm{MEF}$ cell lines. Our data showed that the combination of IR and NU7441 $(1 \mu \mathrm{mol} / \mathrm{L})$ significantly stimulated cell death in MEF cells when compared with IR alone but had a modest effect on DNA-PKcs ${ }^{-/}$and $\mathrm{Ku}^{-/-}$cells (Figure 1C-1E), supporting that potentiation was attributable to DNA-PKcs or Ku70 inhibition. Ku70 is an acknowledged NHEJ repair pathway protein and deletion of Ku70 significantly decreases cell viability by hindering DSB repair [13]. Therefore, we speculated that cells with knockdown of DNA-PKcs were susceptible to IR because of unrepaired DSBs.

\section{Ionizing radiation induces $\gamma \mathrm{H} 2 \mathrm{AX}$ formation and loss of DNA-PKcs, or Ku70 delays DSB repair}

DNA-PKcs participates in multiple aspects of the NHEJ process in DSB repair [12]. $\gamma \mathrm{H} 2 \mathrm{AX}$ serves as a useful surrogate for unrepaired DSB, and its dispersal correlates with DSB repair $[19,20]$. We investigated the capacity of DSB repair in MEF, DNA-PKcs ${ }^{-/} \mathrm{MEF}$, and $\mathrm{Ku} 70^{-/-}$MEF cells after exposure to irradiation using $\gamma \mathrm{H} 2 \mathrm{AX}$ foci formation analysis at specific time intervals. Our data showed that $\gamma \mathrm{H} 2 \mathrm{AX}$ foci formation was evident and abundant at $30 \mathrm{~min}$, peaked at $1 \mathrm{~h}$ and then fell gradually in MEF cells (Figure 2). It was similar to MEF cells at 0.5 and $1 \mathrm{~h}$ post-IR for DNA-PKcs ${ }^{-/-}$ and $\mathrm{Ku} 70^{-/-}$MEF cells, whereas the number of $\gamma \mathrm{H} 2 \mathrm{AX}$ foci per cell persisted at a higher level at $3 \mathrm{~h}$ post-IR in DNA-PKCs ${ }^{-/}$and $\mathrm{Ku} 70^{-/-}$MEF cell lines. Moreover, the kinetics of disappearance of $\gamma \mathrm{H} 2 \mathrm{AX}$ foci was much slower in DNA-PKcs ${ }^{--}$and $\mathrm{Ku} 70^{-/-}$MEF cells than in MEF wildtype cells, implying that an inappropriate NHEJ pathway compromised the ability of cells to repair DNA DSBs (Supplementary Figure 1).

\section{Magnitude of unrepaired DSBs is associated with phosphorylation of ATM and CHK1}

Studies have shown overlaps between phosphorylation of DNA-PKcs and $\gamma \mathrm{H} 2 \mathrm{AX}$ foci and phosphorylation of ATR and $\gamma \mathrm{H} 2 \mathrm{AX}$ foci $[11,21]$. To verify the specific link between p-ATM and $\gamma \mathrm{H} 2 \mathrm{AX}$, we observed a colocalization of $\gamma \mathrm{H} 2 \mathrm{AX}$ and p-ATM (Ser1987) foci at $1 \mathrm{~h}$ post-IR in MEF, DNA-PKes ${ }^{-/} \mathrm{MEF}$, and $\mathrm{Ku} 70^{-/-}$ MEF cell lines (Figure 3A). We further investigated whether p-CHK1 (Ser345) and $\gamma \mathrm{H} 2 \mathrm{AX}$ colocalized. Our data showed that p-CHK1 (Ser345) was accumulated at DNA damage sites close to the site of $\gamma \mathrm{H} 2 \mathrm{AX}$ (Figure 3B). All of these data implied an initial role of ATM in DNA repair and the involvement of both the ATM-CHK2 and ATR-CHK1 pathways.

\section{Inactivation of core members of NHEJ in DSB repair implements cell cycle arrest}

To identify whether cell cycle arrest is biologically relevant to radiosensitivity, we performed a radiationinduced cell cycle profile of MEF, DNA-PKcs ${ }^{-/} \mathrm{MEF}$, and $\mathrm{Ku} 70^{-/-}$MEF cell lines. Irradiation induced G2/M phase arrest in MEF cells at $8 \mathrm{~h}$ post-IR (Figure 4A, 4D), which was completely released at $16 \mathrm{~h}$ post-IR with a similar percentage of cells at the G2/M phase. However, irradiated DNA-PKCs ${ }^{-/}$and $\mathrm{Ku}_{70}^{-/-}$MEF cells exhibited a more robust and prolonged G2/M block in the cell cycle than did the wild-type MEF cells (Figure 4B-4D). The percentage of DNA-PKcs ${ }^{-/}$MEF cells in G2/M was $28.7 \%$ and $38.4 \%$ at $16 \mathrm{~h}$ and $24 \mathrm{~h}$ post-IR, respectively. A similar tendency was observed in $\mathrm{Ku} 70^{-/-}$MEF cells (Figure 4E). The G2/M arrest is the last major opportunity for preventing damaged DSBs from being taken into mitosis, which can result in mitotic catastrophe and cell death [22, 23]. Either DNAPKcs or Ku70 knockdown cells could have a pronounced defect in DSB repair, thus leading to G2/M accumulation.

To further examine the effect of DNA-PKcs inactivation on wild-type cells, we co-treated MEF cells with IR at 5 Gy and $2 \mu \mathrm{M}$ NU7441. The population in $\mathrm{G} 2 / \mathrm{M}$ phase was $23.8 \%, 24.4 \%$, and $11.0 \%$ treated with IR alone at 8,16 , and $24 \mathrm{~h}$ post-IR; whereas a remarkable and permanent increase of $19.5 \%, 39.5 \%$, and $35.7 \%$ in $\mathrm{G} 2 / \mathrm{M}$ phase was detected with the combination of IR and NU7441 treatment at 8,16 , and $24 \mathrm{~h}$ post-IR, respectively (Figure $5 \mathrm{~A}-5 \mathrm{C}$ ); which were very similar to those for DNA-PKcs ${ }^{-/-}$MEF cells. The results clearly and 
unequivocally confirmed the interaction between the cell cycle and DSB repair.

\section{The ATM-CHK2 pathway mediates IR-induced cell cycle arrest}

The expression of ATM is activated by IR-induced DSBs and phosphorylates CHK2, which in turn triggers the G1 checkpoint [4]. CHK2 and CHK1 collaboratively function in $\mathrm{G} 2 / \mathrm{M}$ phase arrest [8]. We performed a time course of activation of ATM-CHK2 pathway gene expression after treatment with irradiation in MEF, DNA$\mathrm{PKcs}^{-/-} \mathrm{MEF}$ and $\mathrm{Ku} 70^{-/-}$MEF cells. Phosphorylated ATM (serine 1987) appeared initially (at $15 \mathrm{~min}$ ) and maintained a high level at $24 \mathrm{~h}$ post-IR in $\mathrm{MEF}$ and $\mathrm{Ku} 70^{-/-}$ cells (Figure 6A, 6C) but returned to control level at 6 $\mathrm{h}$ post-IR in DNA-PKcs ${ }^{--}$cells (Figure 6B). Our results showed a concordance with several studies reporting that inhibition of DNA-PKcs causes a reduction in IR-induced phosphorylation of ATM [16]. ATM initiated CHK2 activation, reached a maximum at $15 \mathrm{~min}$ post-IR, and then dropped to negligible levels at $3 \mathrm{~h}$ post-IR (Figure 6A, 6C) in MEF cells, which is consistent with the cell cycle trend of $\mathrm{G} 2 / \mathrm{M}$ arrest being released after $8 \mathrm{~h}$ post-IR in MEF cells (Figure 4D). Of note, phosphorylation of CHK2 in DNA-PKcs ${ }^{-/-}$MEF cells persisted to $24 \mathrm{~h}$ after treatment of irradiation (Figure 6B).

Akt is a downstream protein of PI3K in DDR and modulates G1/S and G2/M transitions [24, 25]. Gradually increasing expression of phospho-Akt (serine 473) after IR may be due to the cascade reaction. Taking these results together, we posited the dependency of IR-induced DSB repair on activation of cell cycle checkpoints.

\section{Activation of the ATR-CHK1 pathway plays a potential role in rejoining DNA DSB}

ATR and its downstream effector CHK1 are hallmark mediators of intra-S phase and G2/M checkpoints, which collaborate to stabilize DSB and promote DNA repair [26-28]. In the present study, ATR was phosphorylated immediately after irradiation and declined in wild-type MEF cells while the level of p-ATR (S428) expression was sustained even at $24 \mathrm{~h}$ in DNA-PKcs ${ }^{-/}$and $\mathrm{Ku}^{-1-}$ MEF cells (Figure 7A-7C). Similarly, phospho-CHK1 was triggered by IR and decreased at $3 \mathrm{~h}$ in MEF cells, and remained unchanged until $24 \mathrm{~h}$ after treatment in DNA$\mathrm{PKcs}^{-/-}$and $\mathrm{Ku} 70^{-/-} \mathrm{MEF}$ cells (Figure 7A-7C), indicating
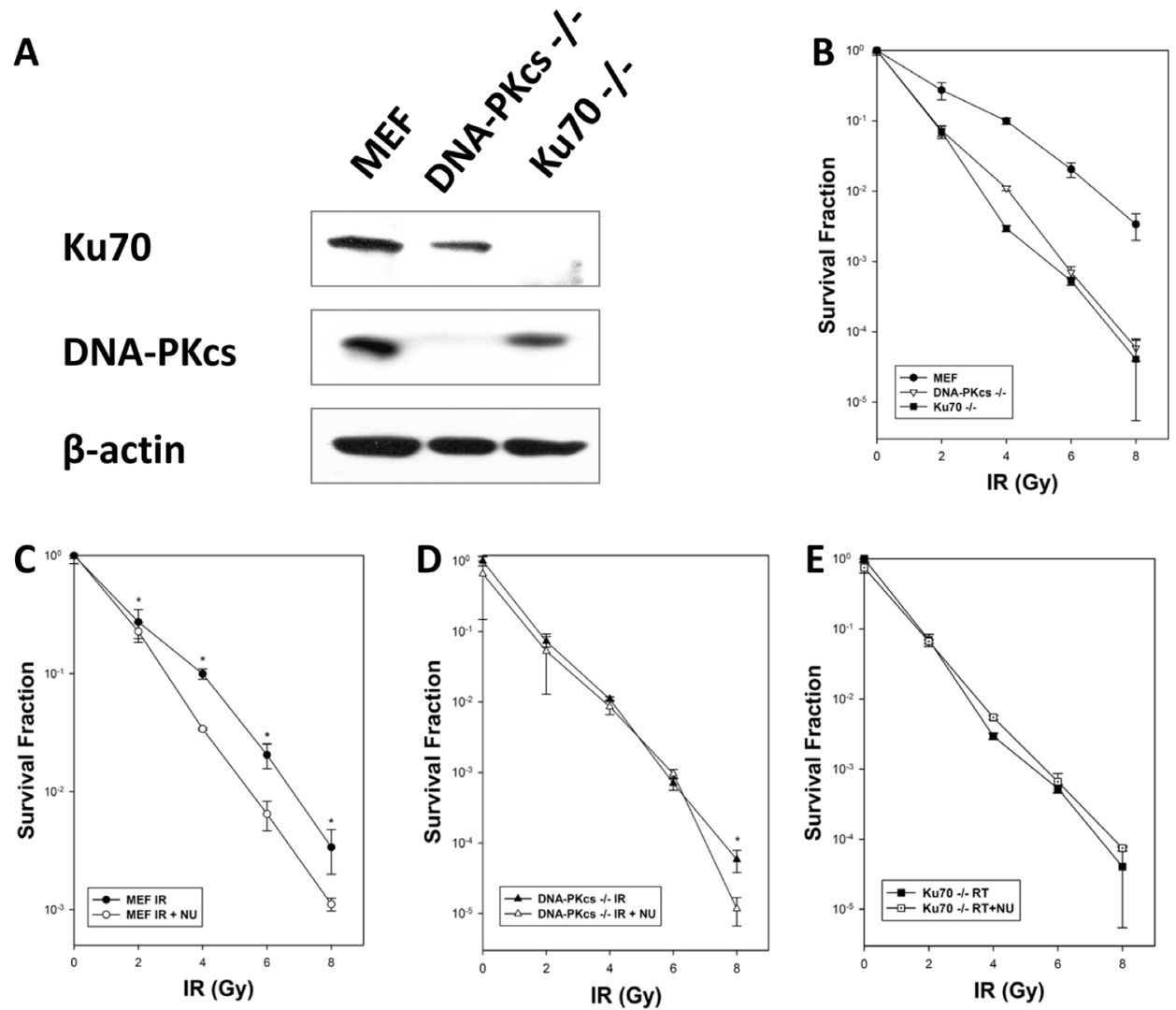

Figure 1: Cellular radiosensitivity depends on NHEJ after exposure to ionizing radiation (IR). (A) Western blot analysis showed expression of Ku70 and DNA-PKcs proteins in MEF, DNA-PKcs ${ }^{-/} \mathrm{MEF}$, and $\mathrm{Ku} 70^{-/-} \mathrm{MEF}$ cells. (B) MEF, DNA-PKcs ${ }^{-/} \mathrm{MEF}$, and $\mathrm{Ku}_{70}{ }^{--}$MEF cells were treated with various X-ray doses. $\mathrm{MEF}(\mathbf{C}), \mathrm{DNA}-\mathrm{PKcs}^{-/}(\mathbf{D})$, and $\mathrm{Ku}_{70^{--}}(\mathbf{E})$ cells were exposed to IR alone or in combination with NU7441 $(1 \mu \mathrm{M})$ for $16 \mathrm{~h}$ before seeding for colony formation. Clonogenic survival data are means of three independent experiments $\pm \mathrm{SD}$. 
that it may still affect cell cycle arrest at $24 \mathrm{~h}$ after IR in cells deficient in the NHEJ pathway. The G2/M delay could result from the inability of DNA-PKcs ${ }^{-/}$or $\mathrm{Ku} 70^{-/-} \mathrm{MEF}$ cells to repair DSB, preventing their entry into mitosis in the cell cycle.

\section{Inhibition of DSB NHEJ repair mediates radiosensitivity in SUNE-1 cells}

Radiotherapy is currently the standard of treatment for NPC. Therefore, we studied SUNE-1 cells to test whether inactivation of DNA-PKcs sensitizes human NPC cells to IR. Our data showed that the combined treatment of irradiation with NU7441 significantly decreased cell viability (Figure 8A), confirming the role of DNA-PKcs in IR-induced cytotoxicity.

We further monitored the fate of DSBs after irradiation. DSBs were completely repaired until $24 \mathrm{~h}$, and the kinetics in disappearance of $\gamma \mathrm{H} 2 \mathrm{AX}$ foci was observed to be similar by normalizing the quantified nuclear foci (Figure $8 \mathrm{~B}$ ). The combination of IR and NU7441 prolonged the persistence of $\gamma \mathrm{H} 2 \mathrm{AX}$ foci at relatively higher levels at 6 and $12 \mathrm{~h}$ post-IR when compared to irradiation alone (Figure 8C). We consistently quantified the number of foci per cell or per square millimeter, indicating significant $\gamma \mathrm{H} 2 \mathrm{AX}$ foci formation in the combined treatment group (Figure 8D-8E).

To investigate the role of cell cycle checkpoints in SUNE-1 cells after exposure to IR and the mechanism of DNA-PKcs-mediated radiosensitivity, we conducted a western blot analysis to examine the gene expression of the ATM-CHK2 and ATR-CHK1 signaling pathways. We found that the level of phospho-CHK2 reached a maximum at $15 \mathrm{~min}$ and fell to normal at $3 \mathrm{~h}$ post-IR which was accompanied by activation of ATM. Phosphorylation of ATR and phosphorylation of CHK1 persisted to $12 \mathrm{~h}$ post-IR (Figure 8F). The DNA-PKcs is phosphorylated by itself and ATM, which is crucial for NHEJ and cellular radioresistance [29]. Of interest, we discovered that phosphorylation of DNA-PKcs (S2056) was slower than that of ATM and phospho-DNA-PKcs persisted at a high level at 1 to $6 \mathrm{~h}$ post-IR (Figure 8F).

\section{DISCUSSION}

We have found that a mechanism of DNA-PKcs activation mediated by cell cycle checkpoints is required for initiating the NHEJ repair pathway in response to irradiation. DNA-PKcs deficiency due to gene knockout or inhibition radiosensitizes MEF cells, impairs DSB repair, and prolongs cell cycle arrest. Inhibition of DNA-PKcs enhances sensitivity to irradiation in human NPC cells.

We previously confirmed that solid mouse tumors could be radiosensitized by heat-shock-induced expression of antisense Ku70 RNA, which inhibited expression of $\mathrm{Ku} 70$ [14]. Human glioma U-87 MG cells and colorectal carcinoma HCT-8 cells with depletion of

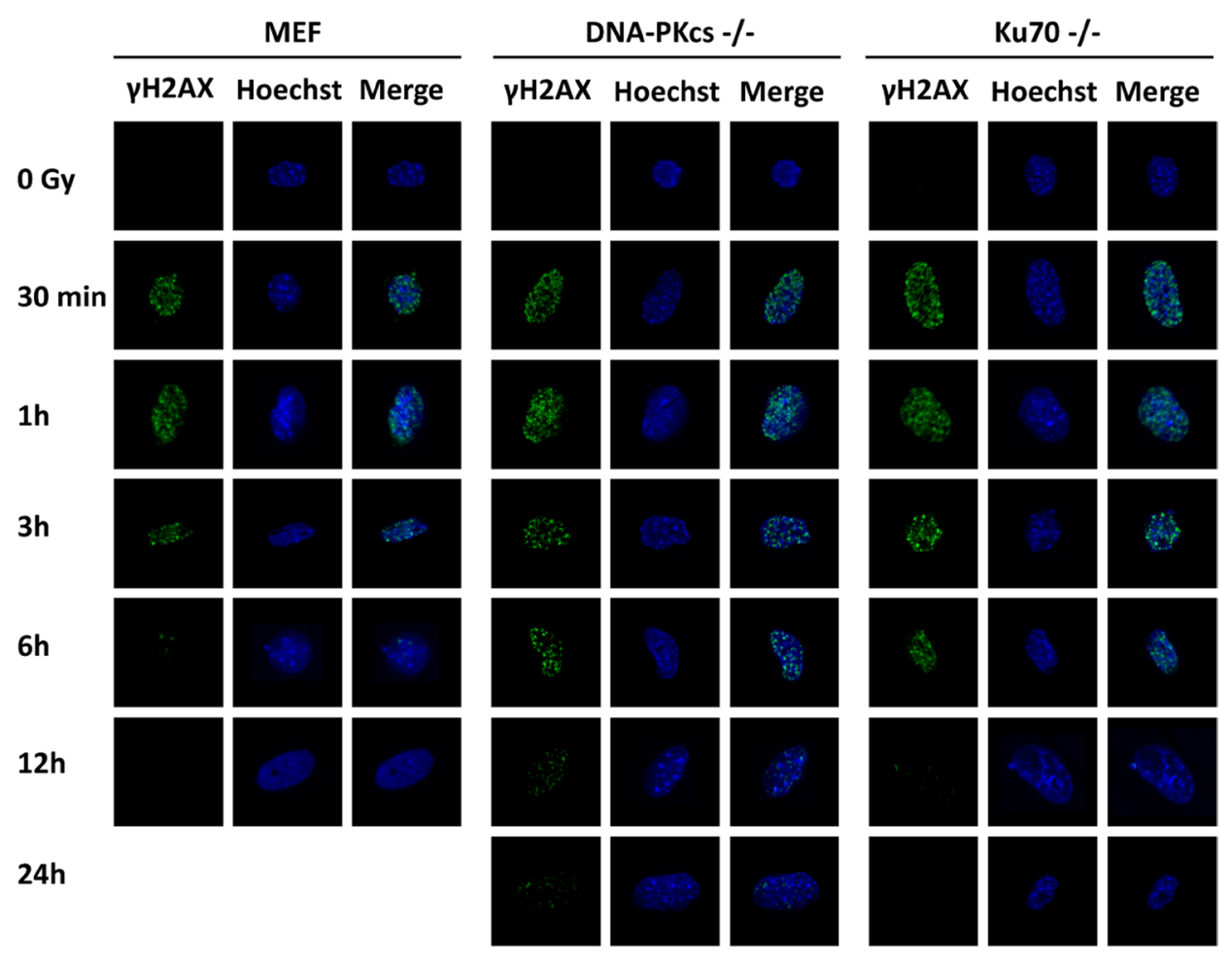

Figure 2: $\gamma \mathrm{H} 2 \mathrm{AX}$ foci formation is detected in MEF, DNA-PKes ${ }^{-/-}$MEF, and Ku $\mathbf{7 0}^{-/-}$MEF cells. $\gamma \mathrm{H} 2 \mathrm{AX}$ foci were formed immediately after 5 Gy X-ray and the resolution of it delayed in NHEJ repair-deficient cells. Representative photomicrographs $(\times 1000$ magnification) shown. 
the $\mathrm{Ku} 70 \mathrm{NH}_{2}$-terminal by a dominant-negative fragment of Ku70 (DNKu70) are vulnerable to irradiation [13]. All of these findings demonstrate that $\mathrm{Ku} 70$ is critical to tumor radiosensitivity in vivo and in vitro. In the present study, we have for the first time discovered the evidence that DNA-PKcs ${ }^{-1} \mathrm{MEF}$ cells exhibit radiosensitivity similar to $\mathrm{Ku} 70^{-/-}$MEF cells and that the addition of DNA-PK inhibitor leads to a modest effect on both, indicating that the role of DNA-PKcs in DSB repair after irradiation resembles that of $\mathrm{Ku} 70$ in NHEJ.

ATM, ATR, and DNA-PKcs are separately recruited to the radiation-induced DNA damage site by interaction with Nbs1, ATRIP, and Ku80 [30]. $\gamma \mathrm{H} 2 \mathrm{AX}$ is necessary to stimulate the DSB response to irradiation and is phosphorylated in the vicinity of DSBs by DNA-PKcs and ATM $[29,31,32]$. The manner of their phosphorylation overlaps [33, 34]. DNA-PKcs-deficient cells exhibit a higher level of $\gamma \mathrm{H} 2 \mathrm{AX}$ whereas the cells in the absence of ATM markedly suppress $\gamma \mathrm{H} 2 \mathrm{AX}$ formation $[35,36]$. Our results have consistently revealed that irradiation induces more DSBs and that the velocity of DSB repair is significantly slower in DNA-PKcs ${ }^{--} \mathrm{MEF}$ cells than in wild-type MEF cells. These results may suggest that a lack of DNA-PKcs has a modest effect on initiating DDR but severely interferes with DSB repair, which would influence genomic integrity.

Our previous data showed that DNA-PKcs selectively aborts apoptosis in mouse thymocytes whereas ATM disrupts G1/S cell cycle arrest [37]. Our present results indicate that the percentage of cells in $\mathrm{G} 2 / \mathrm{M}$ phase was higher and that $\mathrm{G} 2 / \mathrm{M}$ phase arrest persisted longer in $\mathrm{Ku}_{70}^{--} \mathrm{MEF}$ cells than in DNA-PKcs ${ }^{-/} \mathrm{MEF}$ cells, possibly in part due to activation of the G2/M cell cycle entry regulators ATR and CHK1. They are nearly dephosphorylated in DNA-PKcs ${ }^{-/}$MEF cells $24 \mathrm{~h}$ postIR but are retained in $\mathrm{Ku} 70^{-1-} \mathrm{MEF}$ cells. The tumor
A

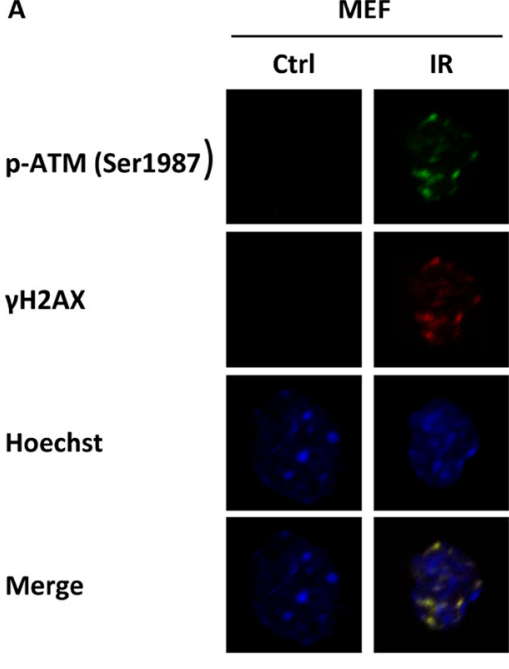

B

MEF
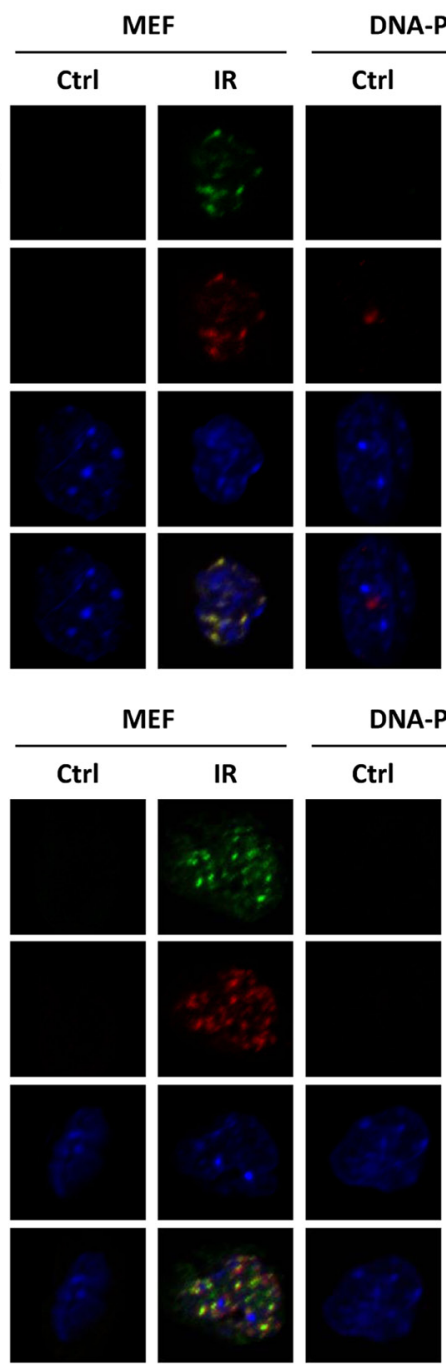
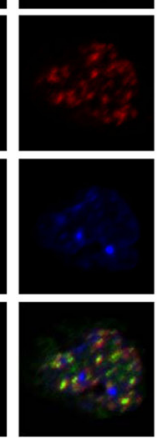

DNA-PKCS -/-
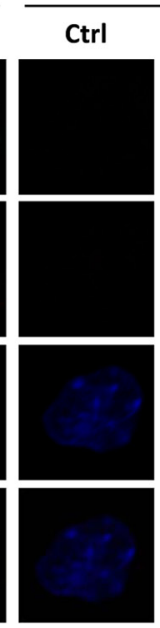

cs -/-
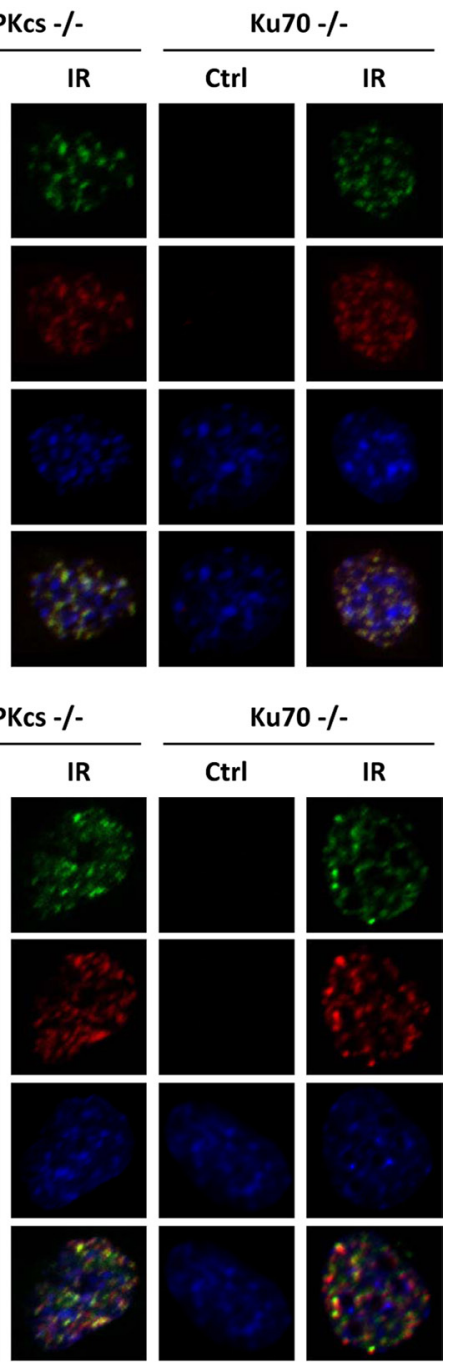

Figure 3: $\gamma \mathrm{H} 2 \mathrm{AX}$ is associated with phosphorylation of ATM and CHK1. MEF cells with knockdown of DNA-PKcs and Ku70 were irradiated with 5 Gy X-ray and co-immunofluorescence stained with $\gamma H 2 A X$ antibody and p-ATM (Ser1987) antibody (A), or with $\gamma \mathrm{H} 2 \mathrm{AX}$ antibody and p-CHK1 (Ser345) antibody (B) at $1 \mathrm{~h}$ post-irradiation. Nuclei were visualized with Hoechst 33342 staining. Representative photomicrographs $(\times 1000$ magnification $)$ shown. 


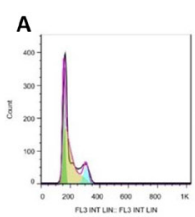

Ctrl

B

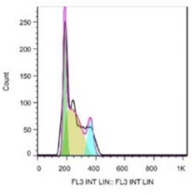

Ctrl

C

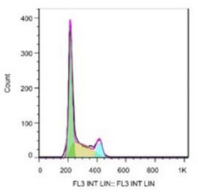

Ctrl

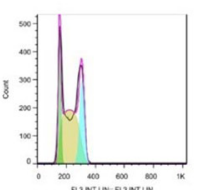

$8 \mathrm{~h}$

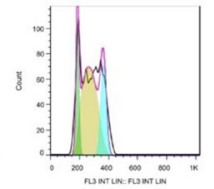

8 h

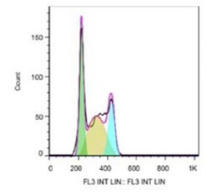

$8 h$

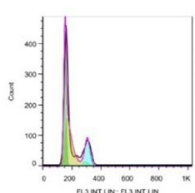

$16 \mathrm{~h}$

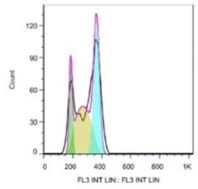

16h

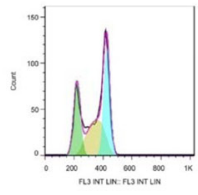

16h

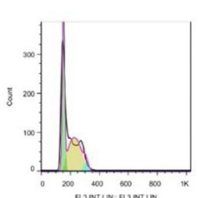

$24 \mathrm{~h}$

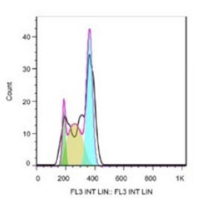

$24 \mathrm{~h}$

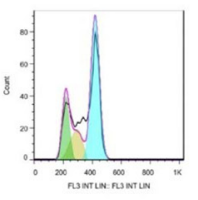

$24 \mathrm{~h}$

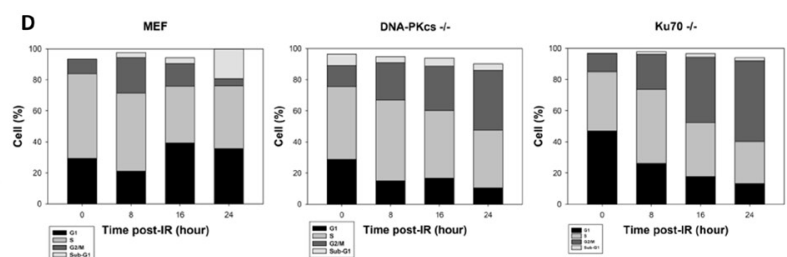

E

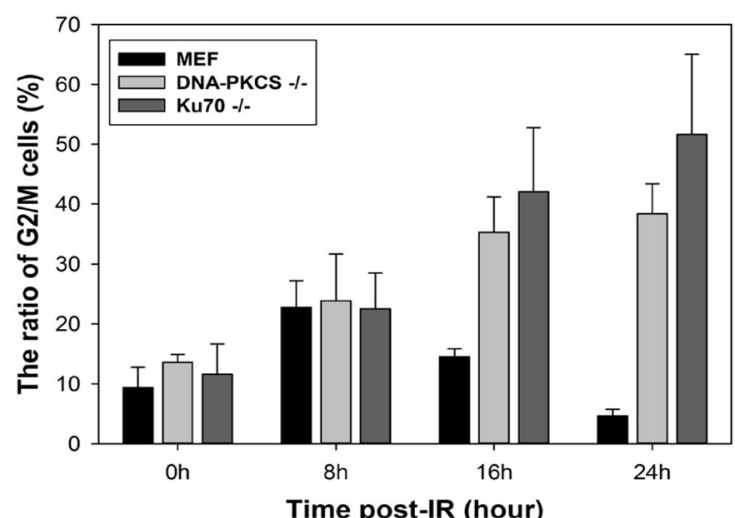

Figure 4: Deficiency in NHEJ repair results in cell cycle arrest. Cell cycle distribution in asynchronous MEF (A), DNA-PKcs ${ }^{-1}$ (B), and $\mathrm{Ku}^{--\digamma}$ (C) cells at indicated times post-IR (5 Gy) was assayed by flow cytometric analysis (FACS) using propidium iodide (PI) staining for DNA content. The proportion of G1, S, and G2/M cells (D) and G2/M phase arrest (E) post-IR was determined. Data are means $\pm \mathrm{SD}$ of the percentages of cells of three independent experiments.

A
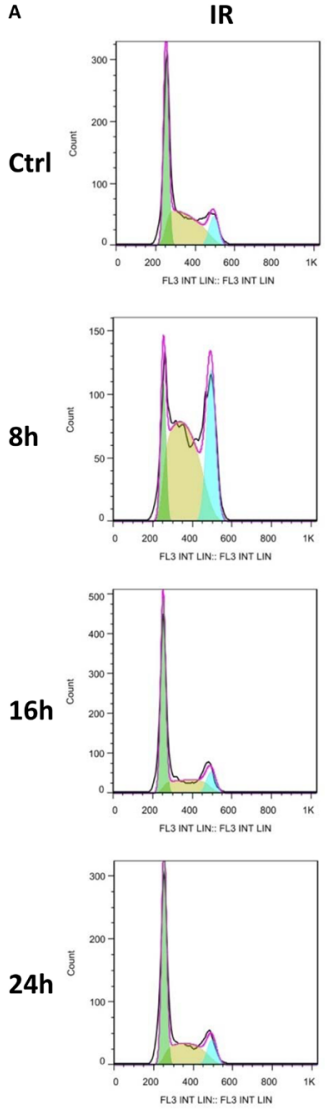
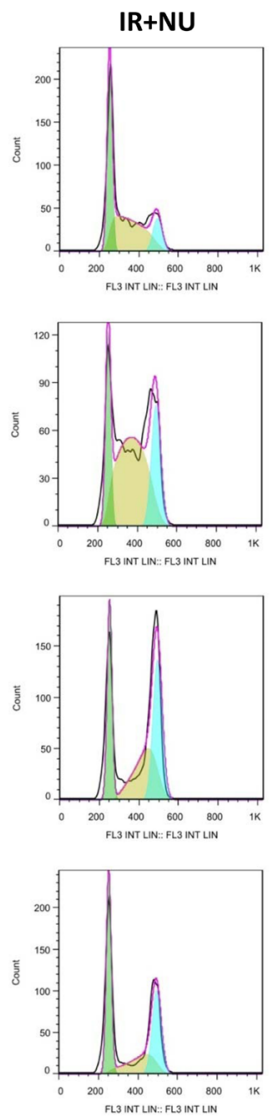

B

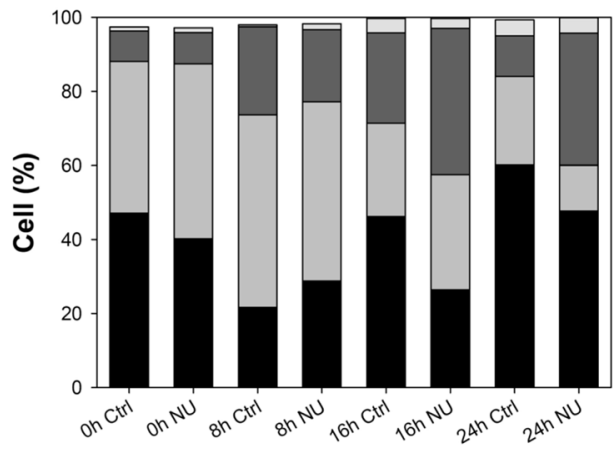

Time post-IR (hour)

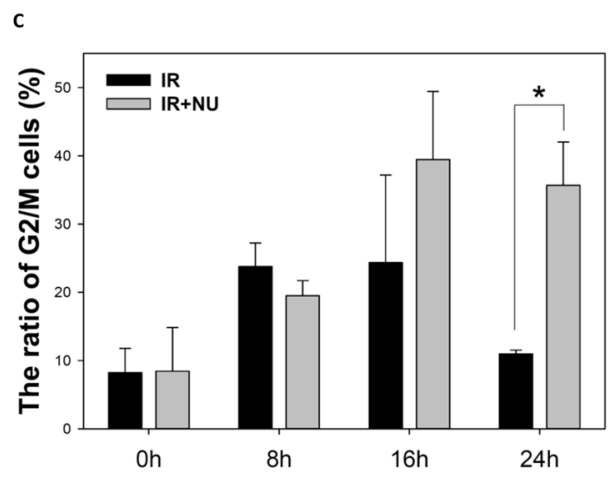

Figure 5: Inhibition of DNA-PKes by NU7441 prolongs G2/M phase arrest. (A) Cells were pretreated with $2 \mu \mathrm{M}$ NU7441 for $1 \mathrm{~h}$ and exposed to $5 \mathrm{~Gy} \mathrm{IR}$. Cell cycle progression was monitored. (B) Cell cycle distribution in asynchronous MEF was measured at 8, 16, and $24 \mathrm{~h}$ post-IR. (C) Percentage of cells in G2/M phase. Data are means \pm SD of the percentages of cells of three independent experiments. 
suppressor protein p53, a downstream substrate of ATM, is accumulated during DDR and participates in cell cycle arrest $[38,39]$. Phospho-p53 drops to normal levels at $8 \mathrm{~h}$ post-IR in DNA-PKcs ${ }^{-/-}$MEF cells but persists to $16 \mathrm{~h}$ postIR in $\mathrm{Ku}^{-10^{--}} \mathrm{MEF}$ cells, indicating a role of $\mathrm{Ku} 70 / 80$ in activating the ATM and ATR signaling pathways [40]. This may explain our observation that the level of phospho-ATM is maximized at $1 \mathrm{~h}$ and minimized at $6 \mathrm{~h}$ post irradiation in
DNA-PKes ${ }^{-/-}$MEF cells while the level of phospho-ATM expression were stabilized in $\mathrm{Ku} 70^{-/-} \mathrm{MEF}$ cells.

Our research has demonstrated that the level of $\gamma \mathrm{H} 2 \mathrm{AX}$ foci returns to the baseline at $6 \mathrm{~h}$ post-irradiation in wild-type MEF cells (Figure 2); whereas DSBs are present at a high level at 6 and $12 \mathrm{~h}$ and are completely repaired at $24 \mathrm{~h}$ post irradiation in tumor cells (Figure $8 \mathrm{~B}$ ). Blunt et al. identified a role of DNA-PKcs in V(D)

A

Post-IR (hour)

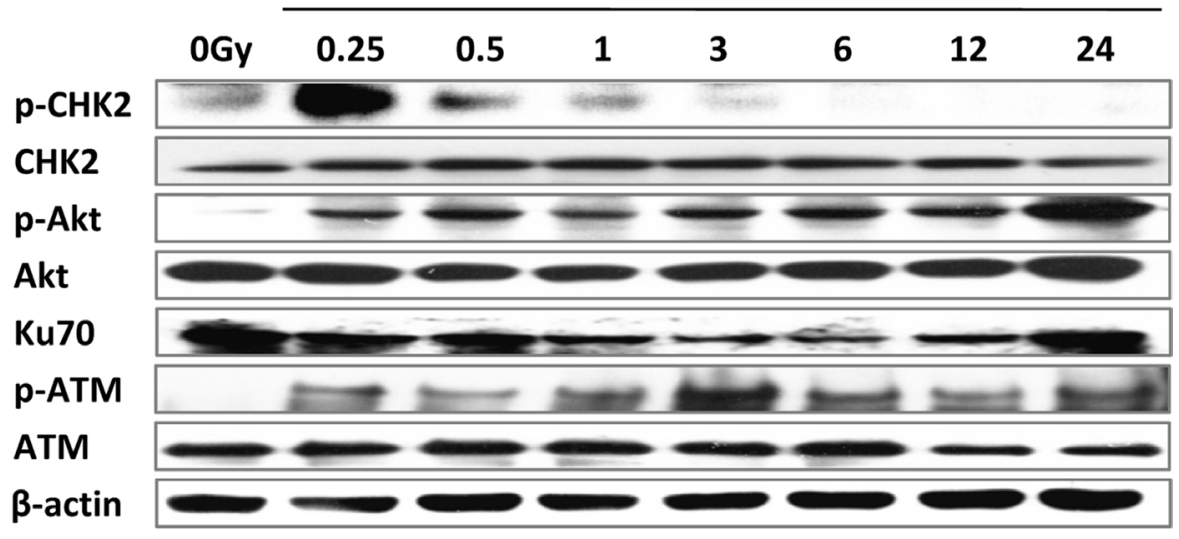

B

Post-IR (hour)

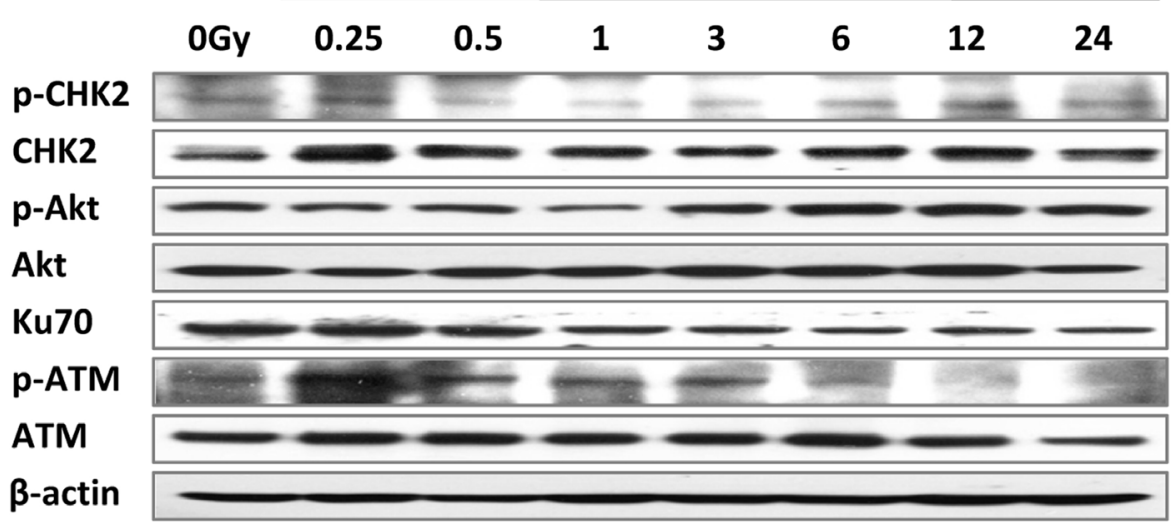

C

\begin{tabular}{llllllll} 
& \multicolumn{8}{c}{ Post-IR (hour) } \\
\cline { 2 - 8 } OGy & 0.25 & 0.5 & 1 & 3 & 6 & 12 & 24
\end{tabular}

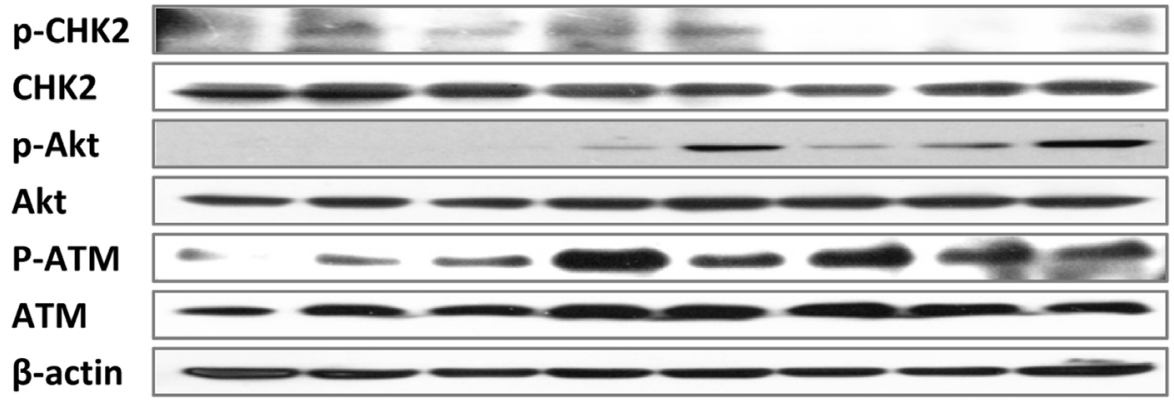

Figure 6: The ATM-CHK2 pathway interacts with the NHEJ repair pathway. Irradiation at 5 Gy up-regulated cell cycle checkpoint signaling in MEF (A), DNA-PKcs ${ }^{--}(\mathbf{B})$, and $\mathrm{Ku}^{-/-}(\mathbf{C})$ cells. Whole cell extract was prepared from untreated cells or collected at various times after irradiation and subjected to western blot analysis. $\beta$-actin was used as the loading control. Representative image from three independent experiments is shown. 
$\mathrm{J}$ recombination and DSB repair, which functions as a radiosensitizer following irradiation [41]. NU7441 is a selective DNA-PK inhibitor which may sensitize cells to irradiation [42]. Preclinical studies have shown that NU7441 radiosensitizes hepatocellular carcinoma, prostate cancer, and breast cancer cell lines [43-45]; whereas its effect remains unclear in NPC cell lines. Of note, we have discovered the first evidence of a striking escalation of $\gamma \mathrm{H} 2 \mathrm{AX}$ foci in SUNE-1 cells treated with irradiation and NU7441 when compared with those treated with irradiation alone at 6 and 12 h. $\gamma \mathrm{H} 2 \mathrm{AX}$ foci almost disappeared in $\mathrm{Ku} 70^{-/-}$MEF cells $12 \mathrm{~h}$ after irradiation

A

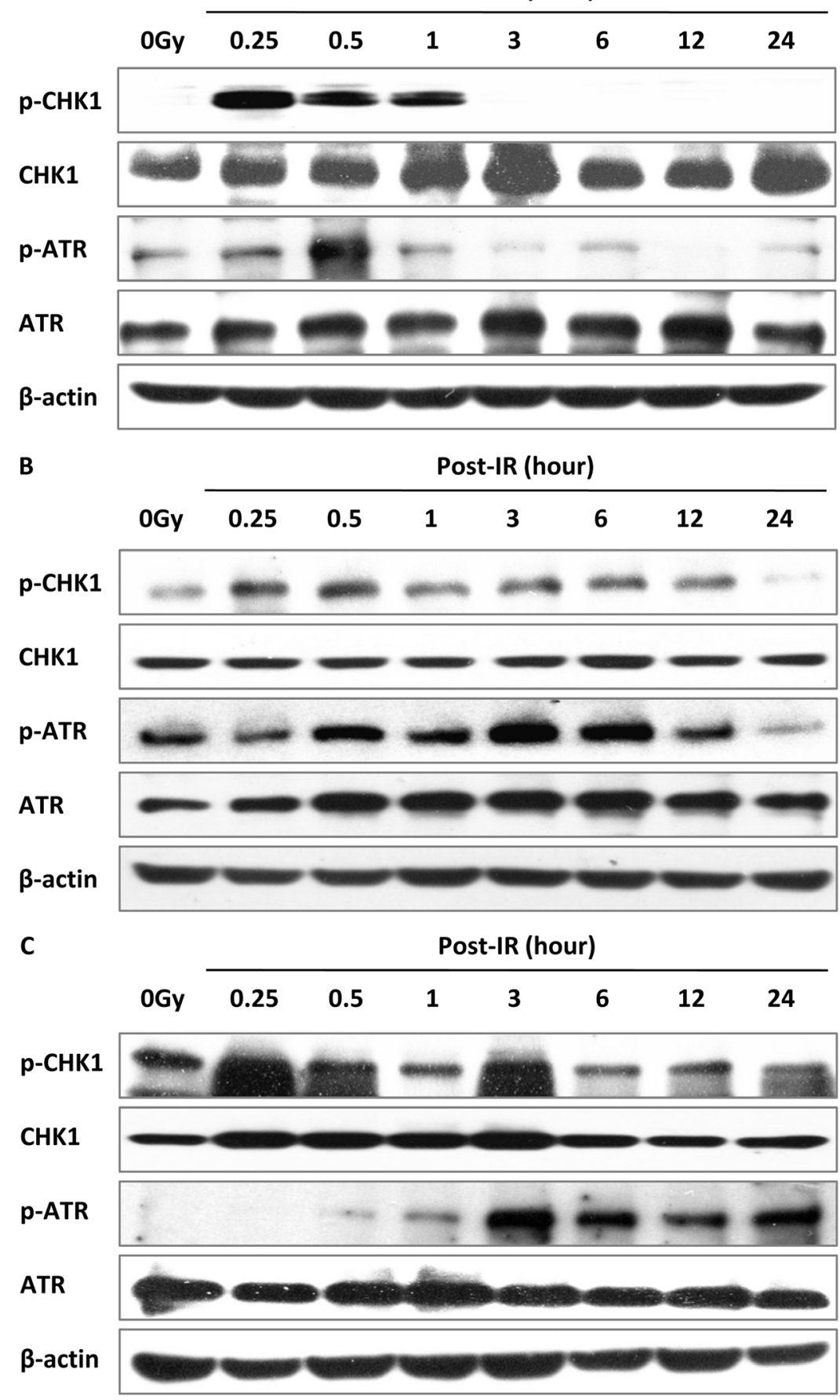

Figure 7: Activation of the ATR-CHK1 pathway is related to DSB repair. ATR-CHK1 pathway proteins were activated post-

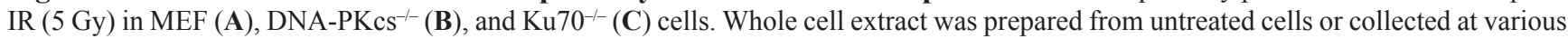
times after irradiation and subjected to western blot analysis. $\beta$-actin was used as the loading control. Representative image from three independent experiments is shown. 
but persisted in DNA-PKcs ${ }^{-/-}$MEF cells, indicating that suppression of DNA-PKcs activity can radiosensitize tumor cells rather than normal cells and might offer a promising therapy paradigm.

In conclusion, our results support the notion that radiosensitizing NHEJ repair-deficient cells is mediated by cell cycle checkpoints by delaying DNA repair, blocking cell cycle progression, and promoting apoptosis. NPC cells are susceptible to combined treatment with DNAPK inhibitor and irradiation due to a resulting deficiency in DSB repair and activation of the cell cycle checkpoint.
Cumulatively, the difference in DSB repair between normal and tumor cells in the suppression of DNAPKcs activity offers promise for the development of new radiation-related therapeutic approaches.

\section{MATERIALS AND METHODS}

\section{Cell lines and treatments}

DNA-PKes ${ }^{-/}, \mathrm{Ku}_{70}^{-/-}$, and wild-type mice on 129 genetic backgrounds were bred as previously reported [46, 47].
A

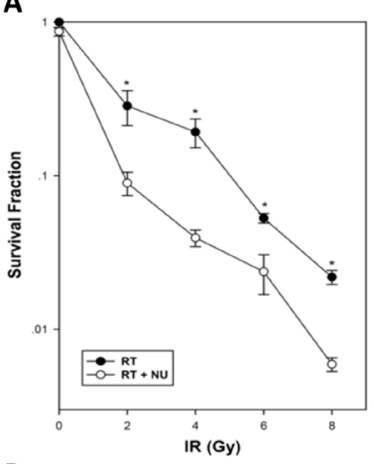

B

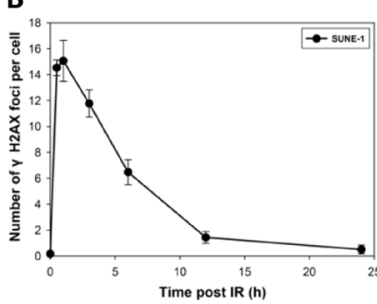

D

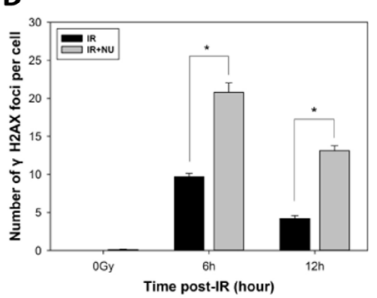

E

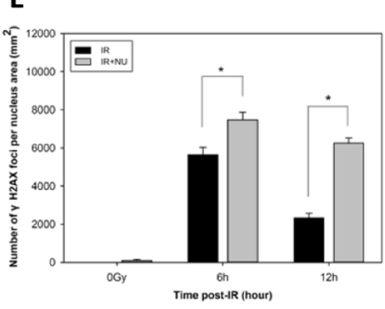

C

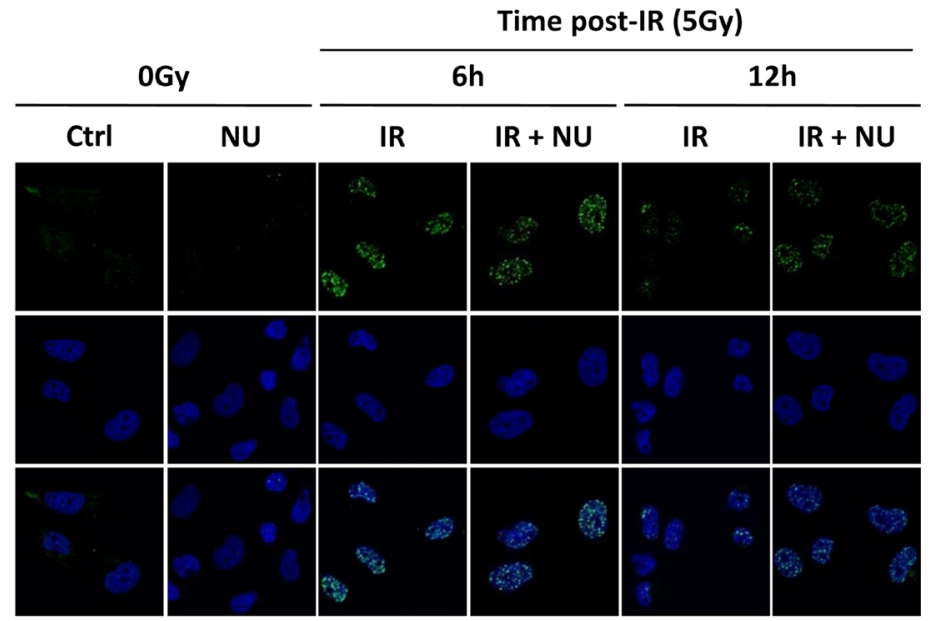

$\mathbf{F}$

p-CHK1

CHK1

p-CHK2

CHK2

Ku70

p-ATR

ATR

p-ATM

ATM

p-DNA-PKcs

DNA-PKCS

$\beta$-actin

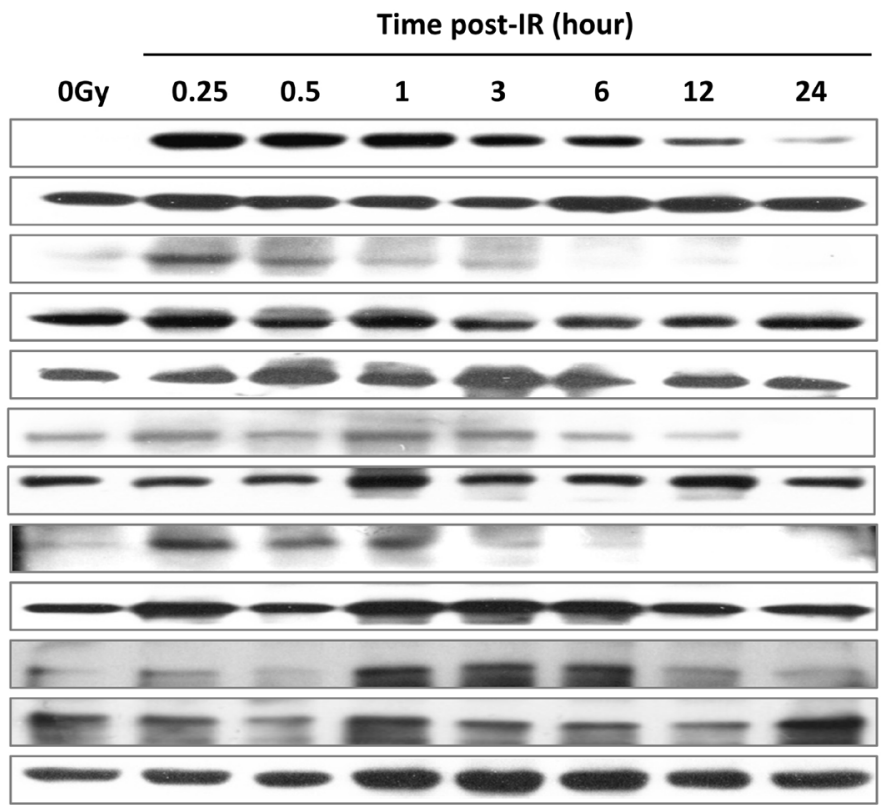

Figure 8: Inhibition of DNA repair induces radiosensitivity in nasopharyngeal carcinoma. (A) Sensitization of nasopharyngeal carcinoma to IR was determined by clonogenic survival of SUNE-1 cells. Data are means \pm SD from three independent experiments. (B) Average number of $\gamma \mathrm{H} 2 \mathrm{AX}$ foci per cell after exposure to 5 Gy IR in SUNE-1 cells, calculated using more than 30 cells. Data are mean \pm SEM. (C) Attenuation of DNA-PKcs interfered with DNA repair. The cells were fixed at 6 or $12 \mathrm{~h}$ after treatment with IR at 5 Gy or a combination of IR and NU7441 $(2 \mu \mathrm{M})$. Representative photomicrographs $(\times 1000$ magnification $)$ are shown. Average number of foci per cell (D) and average number of foci per nucleus area $\left(\mathrm{mm}^{2}\right)(\mathbf{E})$ were calculated by counting at least 30 nuclei. Data are mean \pm SEM. (F) Expression of cell cycle checkpoint proteins analyzed by western blot. Whole cell extract was prepared from untreated cells or collected at specific times after irradiation. 
Mouse embryonic fibroblast (MEF) cells from DNA-PKcs ${ }^{--}$, $\mathrm{Ku} 70^{-/-}$, and wild-type animals were isolated from 13.5-dayold mouse embryos, respectively. The genotype of the embryos was determined by PCR, which distinguished the endogenous from the targeted DNA-PKcs allele or Ku70 allele.

NU7441 (Tocris Bioscience), a DNA-PK inhibitor was dissolved in dimethylsulfoxide (DMSO) for $5 \mathrm{mmol} / \mathrm{L}$ stocks and stored at $-20^{\circ} \mathrm{C}$. All drugs were added to cells to a final DMSO concentration of $0.5 \%$. Cells were exposed to X-rays generated by a RAD SOURCE RS2000 irradiator (Rad Source Technologies, Inc.) operating at $25 \mathrm{~mA}$, with a $0.3-\mathrm{mmAl}$ filter and effective photon energy of $160 \mathrm{kV}$. The dose rate at an irradiation distance of $48.6 \mathrm{~cm}$ was $1.31 \mathrm{~Gy} / \mathrm{min}$.

\section{Clonogenic survival assays}

A total of $1.5 \times 10^{5}$ of exponentially growing MEF, DNA-PKcs ${ }^{-/} \mathrm{MEF}$, and $\mathrm{Ku} 70^{-/-} \mathrm{MEF}$ cells and SUNE1 cells were supplemented with control or NU7441 ( $1 \mu \mathrm{M})$-containing medium for $1 \mathrm{~h}$ and then exposed to IR at $0,2,4,6$, or 8 Gy. After IR, the cells were incubated with or without NU7441 for a further $16 \mathrm{~h}$. Cells were harvested and plated at 20-200 colonies per 100-mm dish in triplicate in drug-free medium and left to develop colonies. At 7-10 days later, colonies consisting of more than 50 cells were counted. After correction for plating efficiency, the data for survival colonies were used to plot clonogenic survival curves.

\section{Western blot analysis}

Total protein and phosphorylated protein following IR were analyzed by Western blotting. Briefly, denatured protein $(50 \mu \mathrm{g})$ was resolved by SDS-PAGE $(6 \%$ or $10 \%)$ and then transferred onto a nitrocellulose membrane. Blots were blocked with $5 \%$ non-fat milk and incubated with specific primary antibodies overnight at $4^{\circ} \mathrm{C}$. Primary antibodies against Akt (1:500), phospho-S473 Akt (1:500), CHK1 (1:500), phosphor-S345 CHK1 (1:500), CHK2 (1:500), ATR (1:500), phosphor-S428 ATR (1:500), ATM (1:500), and rabbit/mouse horseradish peroxidase-conjugated secondary antibodies $(1: 2000)$ were purchased from Cell Signaling Tech (CST). AntiKu70, anti-phospho-T68 CHK2, and anti-phospho-S2056 DNA-PKcs were from Abcam. Anti-phospho-S1987 ATM, anti-DNA-PKcs, and $\beta$-actin were from R\&D, Santa Cruz, and Millipore, respectively. Bands were detected with ECL Western Blotting Substrate (Millipore).

\section{Immunofluorescence microscopy}

For the foci assay, cells were seeded on coverslips (Electron Microscopy Sciences) for more than $24 \mathrm{~h}$ and exposed to IR at $5 \mathrm{~Gy}$. To investigate the efficiency of NU7441, the cells were incubated with or without $2 \mu \mathrm{M}$
NU7441 $1 \mathrm{~h}$ before irradiation with 5 Gy X-ray and collected at the indicated time point. Cells were fixed with $4 \%$ paraformaldehyde, permeabilized with $0.2 \%$ Triton $\mathrm{X}-100$, and blocked with $3 \%$ bovine serum albumin. The cover slips were incubated with the primary mouse monoclonal antibody for $\gamma \mathrm{H} 2 \mathrm{AX}$ (1:200, Millipore) overnight at $4{ }^{\circ} \mathrm{C}$. For visualizing colocalization, cells were collected $1 \mathrm{~h}$ post-irradiation and incubated with mouse anti-phospho-ATM antibody (Santa Cruz) and rabbit anti- $\gamma \mathrm{H} 2 \mathrm{AX}$ antibody (CST) or rabbit antiphospho-CHK1 antibody (CST) and mouse anti- $\gamma \mathrm{H} 2 \mathrm{AX}$ antibody (Millipore). The cells were incubated with Alexa Fluor 488/555-conjugated secondary antibody (1:250, Life Technologies) for $1.5 \mathrm{~h}$ in the dark. Nuclei were stained with Hoechst 33342 (Sigma-Aldrich). Images were acquired by a LSM 710 laser-scanning confocal microscope (Zeiss), with foci counted in 30 cells and quantitative image analysis performed by ImageJ.

\section{Fluorescence-activated cell sorting (FACS)}

For cell cycle analysis, cells were irradiated at 5 Gy in the presence or absence of $2 \mu \mathrm{M}$ NU7441. Cells were then collected at specific time points by trypsinization and fixed with $70 \%$ ethanol at $4{ }^{\circ} \mathrm{C}$. Cellular DNA was labeled with propidium iodide (PI) staining solution $(5 \mu \mathrm{g} / \mathrm{mL}$ PI, $250 \mu \mathrm{g} / \mathrm{mL}$ DNase-free RNase, $0.1 \%$ Triton X-100) for $30 \mathrm{~min}$ at $37^{\circ} \mathrm{C}$. The distribution of cell cycle phases of at least 10,000 cells was determined using a FACS flow cytometer (Beckman, Gallios), and the proportion of cells at different phases was gated and calculated using Flowjo 7.6.1 software.

\section{Statistical analysis}

The data were presented as the mean $\pm \mathrm{SD}$ of at least three independent experiments. The results were tested for significance using the unpaired Student's $t$ test by Sigma Plot 12.5 software.

\section{CONFLICTS OF INTEREST}

None.

\section{GRANT SUPPORT}

The work has been partly supported by National Institutes of Health (No. PO1 CA115675); National Institutes of Health/National Cancer Institute (No. R33 CA109772); National Natural Science Foundation of China (No. 81172209, 81673088).

\section{Authors' Contributions}

Bixiu Wen, Gloria C. Li, Fuqiu He and Clifton C. Ling conceived and designed the experiments. Jun Dong, 
Chengtao Wang, Tian Zhang, Yufeng Ren and Fuqiu He performed the experiments. Fuqiu He and Zhengyu Wang analyzed the data. Bixiu Wen, Gloria C. Li, Fuqiu He, Clifton C. Ling and Jun Dong wrote the paper.

\section{REFERENCES}

1. Liu P, Gan W, Guo C, Xie A, Gao D, Guo J, Zhang J, Willis N, Su A, Asara JM, Scully R, Wei W. Akt-mediated phosphorylation of XLF impairs non-homologous endjoining DNA repair. Mol Cell. 2015; 57:648-661.

2. Barton O, Naumann SC, Diemer-Biehs R, Kunzel J, Steinlage M, Conrad S, Makharashvili N, Wang J, Feng L, Lopez BS, Paull TT, Chen J, Jeggo PA, et al. Polo-like kinase 3 regulates CtIP during DNA double-strand break repair in G1. J Cell Biol. 2014; 206:877-894.

3. Felgentreff K, Du L, Weinacht KG, Dobbs K, Bartish M, Giliani S, Schlaeger T, DeVine A, Schambach A, Woodbine LJ, Davies G, Baxi SN, van der Burg M, et al. Differential role of nonhomologous end joining factors in the generation, DNA damage response, and myeloid differentiation of human induced pluripotent stem cells. Proc Natl Acad Sci USA. 2014; 111:8889-8894.

4. Curtin NJ. DNA repair dysregulation from cancer driver to therapeutic target. Nat Rev Cancer. 2012; 12:801-817.

5. Foulkes WD, Shuen AY. In brief: BRCA1 and BRCA2. J Pathol. 2013; 230:347-349.

6. Roy R, Chun J, Powell SN. BRCA1 and BRCA2: different roles in a common pathway of genome protection. Nat Rev Cancer. 2012; 12:68-78.

7. Jeggo PA, Geuting V, Lobrich M. The role of homologous recombination in radiation-induced double-strand break repair. Radiother Oncol. 2011; 101:7-12.

8. Bouwman P, Jonkers J. The effects of deregulated DNA damage signalling on cancer chemotherapy response and resistance. Nat Rev Cancer. 2012; 12:587-598.

9. Sulli G, Di Micco R, d'Adda di Fagagna F. Crosstalk between chromatin state and DNA damage response in cellular senescence and cancer. Nat Rev Cancer. 2012; 12:709-720.

10. Malumbres M, Barbacid M. Cell cycle, CDKs and cancer: a changing paradigm. Nat Rev Cancer. 2009; 9:153-166.

11. Tomimatsu N, Mukherjee B, Burma S. Distinct roles of ATR and DNA DNA-PKcs in triggering DNA damage responses in ATM-deficient cells. EMBO Rep. 2009; 10:629-635.

12. Weterings E, Chen DJ. DNA-dependent protein kinase in nonhomologous end joining: a lock with multiple keys? J Cell Biol. 2007; 179:183-186.

13. He F, Li L, Kim D, Wen B, Deng X, Gutin PH, Ling CC, Li GC. Adenovirus-mediated expression of a dominant negative Ku70 fragment radiosensitizes human tumor cells under aerobic and hypoxic conditions. Cancer Res. 2007; 67:634-642.
14. Li GC, He F, Shao X, Urano M, Shen L, Kim D, Borrelli M, Leibel SA, Gutin PH, Ling CC. Adenovirus-mediated heatactivated antisense $\mathrm{Ku} 70$ expression radiosensitizes tumor cells in vitro and in vivo. Cancer Res. 2003; 63:3268-3274.

15. Shang ZF, Huang B, Xu QZ, Zhang SM, Fan R, Liu XD, Wang Y, Zhou PK. Inactivation of DNA-dependent protein kinase leads to spindle disruption and mitotic catastrophe with attenuated checkpoint protein 2 Phosphorylation in response to DNA damage. Cancer Res. 2010; 70:3657-3666.

16. Peng Y, Woods RG, Beamish H, Ye R, Lees-Miller SP, Lavin MF, Bedford JS. Deficiency in the catalytic subunit of DNA-dependent protein kinase causes down-regulation of ATM. Cancer Res. 2005; 65:1670-1677.

17. Chang L, Graham PH, Hao J, Ni J, Bucci J, Cozzi PJ, Kearsley JH, Li Y. PI3K/Akt/mTOR pathway inhibitors enhance radiosensitivity in radioresistant prostate cancer cells through inducing apoptosis, reducing autophagy, suppressing NHEJ and HR repair pathways. Cell Death Dis. 2014; 5:e1437.

18. Toulany M, Mihatsch J, Holler M, Chaachouay H, Rodemann HP. Cisplatin-mediated radiosensitization of non-small cell lung cancer cells is stimulated by ATM inhibition. Radiother Oncol. 2014; 111:228-236.

19. Mah LJ, El-Osta A, Karagiannis TC. gammaH2AX: a sensitive molecular marker of DNA damage and repair. Leukemia. 2010; 24:679-686.

20. Bonner WM, Redon CE, Dickey JS, Nakamura AJ, Sedelnikova OA, Solier S, Pommier Y. GammaH2AX and cancer. Nat Rev Cancer. 2008; 8:957-967.

21. Wang CY, Huang EY, Huang SC, Chung BC. DNA-PK/ Chk2 induces centrosome amplification during prolonged replication stress. Oncogene. 2015; 34:1263-1269.

22. O'Connor MJ. Targeting the DNA Damage Response in Cancer. Mol Cell. 2015; 60:547-560.

23. Dai Y, Grant S. New insights into checkpoint kinase 1 in the DNA damage response signaling network. Clin Cancer Res. 2010; 16:376-383.

24. Xu N, Lao Y, Zhang Y, Gillespie DA. Akt: a double-edged sword in cell proliferation and genome stability. J Oncol. 2012; 2012:951724.

25. Bozulic L, Surucu B, Hynx D, Hemmings BA. PKBalpha/ Akt1 acts downstream of DNA-PK in the DNA doublestrand break response and promotes survival. Mol Cell. 2008; 30:203-213.

26. Weber AM, Ryan AJ. ATM and ATR as therapeutic targets in cancer. Pharmacol Ther. 2015; 149:124-138.

27. Marechal A, Zou L. DNA damage sensing by the ATM and ATR kinases. Cold Spring Harb Perspect Biol. 2013; 5.

28. Shiotani B, Nguyen HD, Hakansson P, Marechal A, Tse A, Tahara H, Zou L. Two distinct modes of ATR activation orchestrated by Rad17 and Nbs1. Cell Rep. 2013; 3:1651-1662.

29. Shrivastav M, De Haro LP, Nickoloff JA. Regulation of DNA double-strand break repair pathway choice. Cell Res. 2008; 18:134-147. 
30. Falck J, Coates J, Jackson SP. Conserved modes of recruitment of ATM, ATR and DNA-PKcs to sites of DNA damage. Nature. 2005; 434:605-611.

31. Caron P, Choudjaye J, Clouaire T, Bugler B, Daburon V, Aguirrebengoa M, Mangeat T, Iacovoni JS, Alvarez-Quilon A, Cortes-Ledesma F, Legube G. Non-redundant Functions of ATM and DNA-PKcs in Response to DNA Double-Strand Breaks. Cell Rep. 2015; 13:1598-1609.

32. Savic V, Yin B, Maas NL, Bredemeyer AL, Carpenter AC, Helmink BA, Yang-Iott KS, Sleckman BP, Bassing CH. Formation of dynamic gamma-H2AX domains along broken DNA strands is distinctly regulated by ATM and MDC1 and dependent upon H2AX densities in chromatin. Mol Cell. 2009; 34:298-310.

33. Stiff T, O’Driscoll M, Rief N, Iwabuchi K, Lobrich M, Jeggo PA. ATM and DNA-PK function redundantly to phosphorylate $\mathrm{H} 2 \mathrm{AX}$ after exposure to ionizing radiation. Cancer Res. 2004; 64:2390-2396.

34. Burma S, Chen BP, Murphy M, Kurimasa A, Chen DJ. ATM phosphorylates histone $\mathrm{H} 2 \mathrm{AX}$ in response to DNA doublestrand breaks. J Biol Chem. 2001; 276:42462-42467.

35. Hartlerode AJ, Morgan MJ, Wu Y, Buis J, Ferguson DO. Recruitment and activation of the ATM kinase in the absence of DNA-damage sensors. Nat Struct Mol Biol. 2015; 22:736-743.

36. Jiang W, Crowe JL, Liu X, Nakajima S, Wang Y, Li C, Lee BJ, Dubois RL, Liu C, Yu X, Lan L, Zha S. Differential phosphorylation of DNA-PKcs regulates the interplay between end-processing and end-ligation during nonhomologous end-joining. Mol Cell. 2015; 58:172-185.

37. Wang S, Guo M, Ouyang H, Li X, Cordon-Cardo C, Kurimasa A, Chen DJ, Fuks Z, Ling CC, Li GC. The catalytic subunit of DNA-dependent protein kinase selectively regulates $\mathrm{p} 53$-dependent apoptosis but not cell-cycle arrest. Proc Natl Acad Sci U S A. 2000; 97:1584-1588.

38. Chen J. The Cell-Cycle Arrest and Apoptotic Functions of p53 in Tumor Initiation and Progression. Cold Spring Harb Perspect Med. 2016; 6.

39. Taylor WR, Stark GR. Regulation of the G2/M transition by p53. Oncogene. 2001; 20:1803-1815.
40. Tomimatsu N, Tahimic CG, Otsuki A, Burma S, Fukuhara A, Sato K, Shiota G, Oshimura M, Chen DJ, Kurimasa A. Ku70/80 modulates ATM and ATR signaling pathways in response to DNA double strand breaks. J Biol Chem. 2007; 282:10138-10145.

41. Blunt T, Finnie NJ, Taccioli GE, Smith GC, Demengeot J, Gottlieb TM, Mizuta R, Varghese AJ, Alt FW, Jeggo PA, Jackson SP. Defective DNA-dependent protein kinase activity is linked to $\mathrm{V}(\mathrm{D}) \mathrm{J}$ recombination and DNA repair defects associated with the murine scid mutation. Cell. 1995; 80:813-823.

42. Helleday T, Petermann E, Lundin C, Hodgson B, Sharma RA. DNA repair pathways as targets for cancer therapy. Nat Rev Cancer. 2008; 8:193-204.

43. Cornell L, Munck JM, Alsinet C, Villanueva A, Ogle L, Willoughby CE, Televantou D, Thomas HD, Jackson J, Burt AD, Newell D, Rose J, Manas DM, et al. DNAPK-A candidate driver of hepatocarcinogenesis and tissue biomarker that predicts response to treatment and survival. Clin Cancer Res. 2015; 21:925-933.

44. Yu L, Tumati V, Tseng SF, Hsu FM, Kim DN, Hong D, Hsieh JT, Jacobs C, Kapur P, Saha D. DAB2IP regulates autophagy in prostate cancer in response to combined treatment of radiation and a DNA-PKcs inhibitor. Neoplasia. 2012; 14:1203-1212.

45. Ciszewski WM, Tavecchio M, Dastych J, Curtin NJ. DNAPK inhibition by NU7441 sensitizes breast cancer cells to ionizing radiation and doxorubicin. Breast Cancer Res Treat. 2014; 143:47-55.

46. Kurimasa A, Ouyang $\mathrm{H}$, Dong LJ, Wang S, Li X, Cordon-Cardo C, Chen DJ, Li GC. Catalytic subunit of DNA-dependent protein kinase: impact on lymphocyte development and tumorigenesis. Proc Natl Acad Sci USA. 1999; 96:1403-1408.

47. Ouyang H, Nussenzweig A, Kurimasa A, Soares VC, Li X, Cordon-Cardo C, Li W, Cheong N, Nussenzweig M, Iliakis G, Chen DJ, Li GC. Ku70 is required for DNA repair but not for $\mathrm{T}$ cell antigen receptor gene recombination In vivo. J Exp Med. 1997; 186:921-929. 